\title{
Legal regulation of investment activity in the republic of Kalmykia in the context of the digital economy development: the civil aspect
}

\author{
Ochir Minkeev 1,*, and Sergey Sharonov ${ }^{2}$ \\ 1 Government Office of the Republic of Kalmykia, Elista, Republic of Kalmykia, Russia, ochir91@mail.ru \\ 2 Moscow University of the Ministry of Internal Affairs of Russia named after V.Ya. Kikot, Moscow, Russia, \\ sharonov345@mail.ru
}

\begin{abstract}
The article uses the means of civil science to identify the problems of applying the normative legal acts of the Republic of Kalmykia regulating the relations of investment activity in the context of the digital economy development. Within the framework of this study, the author systematizes three groups of regulatory legal acts dealing with the relations of investment activity in the Republic of Kalmykia, each containing certain problems. The key problem of the first group, consisting of civil legislation and other acts containing civil law norms, is the lack of a unified approach to regulating investment activities. The second group, which is a set of separate Laws and other regulatory legal acts of the Republic of Kalmykia, dealing with the issues under the joint jurisdiction of the Russian Federation and the Republic of Kalmykia, contains a problem expressed in the lack of proper legal regulation of investment activity in the republic. The problem of the third group, consisting of municipal acts providing legal regulation of relations arising from the management and disposal of municipal property objects that can act as objects of investment activity, is the lack of a legislative basis for the implementation of the public function.
\end{abstract}

\section{Introduction}

The relevance of the topic is due to the rapid development of the digital economy and its penetration into investment activities. Currently, the priority state task is the process of "launching a new investment cycle", which allows significant investment increasing in various segments of "industry, agriculture, and services" [1]. Attention should be paid to the fact that investing in mentioned segments is most widespread in the Republic of Kalmykia territory (hereinafter - RK).

However, as the practice in several countries shows, the future of the Russian economy is not possible without the digitalization of investment activity and its legal regulation, which currently lags behind the needs of civil turnover.

Currently, the digital transformation of the national economy is carried out within the framework of the national project "National Program "Digital Economy of the Russian Federation", aimed at, among other objectives, increasing domestic costs for the development of the digital economy from all sources of funds [2].

To date, the results of these policy documents implementation are the introduction of amendments to civil legislation in terms of adding digital rights to the list of civil rights objects [3], the adoption of a Federal
Law regulating the process of investing and attracting investment using investment platforms [4]. Additionally, these acts do not actually detail the legal regulation specifics of investment activities in the RK, which, definitely, reduces its effectiveness for the civil turnover participants.

\section{Problem Statement}

In the RK the implementation of this national project is carried out through the execution of several regional programs that are correlated with federal projects: digital technologies, digital public administration, personnel for the digital economy, information infrastructure, information security [5].

In this regard, it should be noted that measures aimed at regulating the digital environment are carried out exclusively at the federal level, which, without taking into account the specifics of investment activity in the $\mathrm{RK}$, is not always effective.

This circumstance is explained, among other things, by the fact that, according to paragraph "o" of Article 71 of the Constitution of the Russian Federation, civil legislation is under the jurisdiction of the Russian Federation.

\footnotetext{
* Corresponding author: ochir91@mail.ru
} 
However, the current state of investment activity in the Republic of Kazakhstan requires a comprehensive approach to its legal regulation. In practice, this means the application of the norms not only of civil legislation but also of other branches of law, which norms directly affect the legal relations developing in certain areas of investment activity carried out in the RK. Also, it should be noted that this regulation has problems that do not allow achieving the goals of the national project.

\section{Research Questions}

In the question of studying the problems of legal regulation of investment relations that are developing in the RK, in the context of economic processes digitalization, it is necessary to take into account its complex nature, paying attention to the possibility of its regulation by the norms of both private and public law.

\section{Purpose of the Study}

Thus, the research goal of the publication is to identify the problems of complex legal regulation of investment activities in the RK in the context of economy digitalization. To meet this goal, it is necessary to solve two tasks: first, to argue that the complex nature of the regulation under study actually means the application of the norms of other branches of law, which objects are objects of investment activity (land, housing, etc.), and the relations developing in this case, along with civil legislation, can be regulated by acts of other sectorial affiliation, the right to adopt these acts is granted to the relevant bodies of the RK; second, based on the analysis of regulatory legal acts, to identify and resolve problems arising in the process of their application in the RK.

Let us sequentially consider the solution of the tasks set, paying attention to the features of the methodology designed by the authors: the identification of problems in the studied area (the second task) will be carried out sequentially in the context of solving the first task of the publication.

In the context of solving the first task, it should be noted that according to the investment strategy of the RK, investment activities in the RK are carried out in several economic sectors of the RK, which study on investment attractiveness requires the application of cluster analysis [6]. As a result of cluster modeling, the first cluster includes two sectors - "Agriculture" and "Education"; the second cluster - "Industry"; the third cluster - "Construction", "Trade", "Transport and Communications"; the fourth cluster - "Hotels and restaurants".

It is possible to achieve the objectives of the RK investment strategy, in particular through improving the legislation under the joint jurisdiction of the Russian Federation and the RK, including budget legislation, legislation of the RK on taxes and fees, land legislation, etc.

We will evaluate mentioned types of legislation while focusing on the classification of the relevant regulatory legal acts and the degree of their impact on the essence of the activity under study.

According to the results of the analysis, the regulatory legal acts dealing with the investment activity relations in the RK can be systematized into three groups. Thus, the first group comprises civil legislation, which includes codified acts, laws of the Russian Federation and federal laws, and other acts containing the provisions of civil law, including Decrees of the President of the Russian Federation, RF Government Regulations and regulatory legal acts of federal executive bodies. The second group comprises the legislation of the RK, containing the laws of the RK, decrees of the Head of the Republic of Kalmykia, RK Government Regulations and regulatory legal acts of the RK executive authorities. The third group comprises the decision by the representative local bodies and municipal legal acts of the RK municipalities.

The first group of classification should include the Civil Code of the Russian Federation, which structure largely coincides with the content of investment activities in the Russian Federation as a whole and the Republic of Kalmykia in particular. This leads to the conclusion that the Civil Code of the Russian Federation is the fundamental act regulating relations in the studied area. For example, the legal capacity of citizens and legal entities that can act as both investors and customers is determined by subsection 2 "Persons". The norms of Chapter 9 "Transactions", as well as the norms of Section III "The general part of the law of obligations" can be fully used to regulate the relations under study, since the basis for the emergence of investment activity and the means of its legal regulation can be a contract, which in its legal essence is a type of transaction and obligation.

The first group also includes several federal laws, dealing with the relations developing within the process of capital investments, concession agreements, agreements on public-private, municipal-private partnership, in attracting investment using digital platforms, in the issuance, accounting and circulation of digital financial assets, which enter into force on January 10, 2021.

The analysis of the above-mentioned federal laws discloses the key problem of the first group, which is expressed in the application of regulatory legal acts only separately to each type of investment activity, which indicates the lack of a unified approach to regulating investment activity. The need to supplement this regulation with such acts, which could be adopted by the authorized bodies of the RK, is therefore acute. In addition, it is necessary to take into account the current trends of legal regulation, in particular, the penetration of digitalization elements into this process [7].

The content of the second group is represented by the Laws of the Republic of Kalmykia "On the tax on the property of organizations", "On the investment fund of the Republic of Kalmykia", "On state support and protection of the rights of investment entities in the Republic of Kalmykia", "On the establishment of a reduced rate of corporate income tax credited to the budget of the Republic of Kalmykia for certain 
categories of taxpayers", "On the application of the investment tax deduction for corporate income tax in the territory of the Republic of Kalmykia", Decrees of the Head of the Republic of Kalmykia "On approval of the investment strategy of the Republic of Kalmykia until 2025", "On approval of the investment declaration of the Republic of Kalmykia", Government Regulations of the Republic of Kalmykia "On approval of the procedure for support of investment projects implemented and/or planned for implementation on the principle of "one window" on the territory of the Republic of Kalmykia", "On approval of the rules for capital investments in state-owned objects of the Republic of Kalmykia at the expense of the republican budget", "On approval of the procedure for making decisions on the compliance of large-scale Investment projects with the criteria established by Article 4 of the Law of the Republic of Kalmykia "On the establishment of criteria that

must meet the objects of socio-

cultural and communal purposes, large-

scale investment projects, for the placement (implementa tion) of which it is allowed

to provide a land plot that is in state or municipal owners hip for rent without bidding", etc.

The formation of acts of the second group is dictated by the fact that in accordance with Article 72 of the Constitution of the Russian Federation, the joint jurisdiction of the Russian Federation and the Republic of Kalmykia includes the administrative, administrative procedure, labor, family, housing, land, water, and forest legislation; legislation on subsoil and environmental protection. For the legal regulation of investment activity in the RK, this has the following meaning: 1) the RK has the right to carry out state regulation of investment activities carried out in the form of capital investments by approving inter-municipal investment projects and investment projects for state-owned objects of the RK, establishing the procedure for conducting expert reviews of investment projects, approving the procedure for involving temporarily suspended and abandoned construction projects and objects owned by the RK in the investment process; 2) the possibility of legal regulation that determines the legal status of individual entities and the legal regime of investment objects. Thus, the subjects of investment activity in the RK can be, including the public legal entity - the Republic of Kalmykia represented by the state authorities of the RK [8], and in turn, the objects of investment activity in the RK objects of housing, land, water and other relations.

The analysis of the acts of the second group shows that some of them are not coordinated with each other. This circumstance reveals the main problem of the group under consideration, which is expressed in the lack of proper legal regulation of investment relations in the RK. In this regard, it is proposed to adopt the Law of the Republic of Kalmykia "On Investment Activity in the Republic of Kalmykia", establishing the powers of the RK state authorities in regulating the relations of investment activity in the RK, defining the list of subjects and objects of investment activity in the RK, the procedure for concluding investment agreements to which the public legal entity - the Republic of Kalmykia represented by the RK state authorities is a party, as well as aimed at solving other problems in the field under study. Also, attention should be paid to the fact that "digitalization of the regional economy...should become the main tool..." for its effective development [9].

The third group is due to the amendments to the Constitution of the Russian Federation, according to which local government bodies shall be included in a single system of public authority of the Russian Federation in order to maximise their efficiency in fulfilling tasks in the interests of the people living in the corresponding territory [10].

Thus, local government bodies, within the framework of constitutional provisions implementation in the field of investment activity, have the right to act as its subjects and, through the management of municipal property, have the right to carry out legal regulation of relations concerning the objects (buildings, constructions, structures) of culture and sports, educational, industrial, social infrastructure, etc., which have the potential to act as objects of investment activity.

As rightly pointed out by V.N. Pleskach, the development and concretization of constitutional provisions in legislation is of paramount importance for the implementation of the Constitution of the Russian Federation [11].

In addition, the analysis of the third group leads to the conclusion that the legal regulation of investment activities in the RK by local government bodies is limited to a certain extent due to the lack of a legislative basis for the implementation of public functions in terms of regulating investment activities carried out in the form of capital investments.

\section{Research Methods}

Dialectical, logical, historical, systematic and structural, and other methods of scientific cognition were used in the study.

\section{Findings}

Summarizing up the results of this study, we can draw the following conclusions.

First, the legal regulation of investment activity in the $\mathrm{RK}$ is of complex nature, which is manifested in its impact on the norms of various branches of law, while combining private law and public law relations for the implementation of investment activities.

Secondly, the core issue of legal regulation dealing with investment activity in the RK identified in this publication is the lack of conceptual legal regulation both at the level of civil legislation and at the level of the RK legislation.

Thirdly, at present, proper legal regulation of investment activities in the RK is becoming impossible without the digitalization process, its legal registration should be reflected in the proposed bill. 


\section{Conclusion}

Thus, based on the analysis of public and private legislative means of regulating investment relations, the classification of problems allows us to identify and systematize issues to be addressed in the area under study.

A number of problems concerning legal regulation of investment activity in the RK can be solved by improving the RK legislation through the development and adoption of the Law of the RK "On Investment Activity in the Republic of Kalmykia", making up the legal regulation system of the studied activity and providing provisions on its digitalization.

\section{References}

1. V.V. Putin, Rossiyskaya Gazeta 7 (2020)

2. L.S. Gorskina, \& O.V. Propp Russian Journal of Innovation Economics 9(2), 275-286 (2019)

3. I.M. Konobeevskaya, Izvestiya of Saratov University. New Series. Series Economy. Management. Law 19 (3), 330-334 (2019)

4. Yu.V. Pavlova, Bulletin of the Russian University of Cooperation, 3 (37), 78-84 (2019)

5. T.N. Mikheeva, Courier of Kutafin Moscow State Law University 9 (61), 114-122 (2019)

6. A.A. Mantsaeva, \& T.G. Delikova, Bulletin of the Institute for Integrated Studies of Arid Territories 1(32), 6-19 (2016)

7. V.P. Kamyshansky, Vlast Zakona 1, 14-18 (2019)

8. O.D.

Minkeev, Bulletin of the Volga Region Institute of Administration 3 (54), 127-131 (2016)

9. D.E. Bekbergeneva, Collection of scientific articles on the results of the fourth round table with international participation 2, 27-28 (2020)

10. M.M Mukhlynina, Gosudarstvennaya sluzhba i kadry 2, 30-33 (2020)

11. V.N. Pleskach, Carskosel'skie chtenija, III (XX), 8999 (2016) 